\title{
CORPORATISM AND THE BRITISH CONSTITUTIONAL HERITAGE: EVIDENCES FROM THE HISTORY OF IDEAS
}

O corporativismo e o legado constitucional britânico: evidências da história das ideias

El corporativismo y el legado constitucional británico: evidencias a partir de la historia de las ideas

VALERIO TORREGGIANI ${ }^{\text {I* }}$

http://dx.doi.org/10.1590/S2178-14942018000200003

\footnotetext{
'Università degli Studi della Tuscia. Viterbo, Itália.

*Possui doutorado em Storia dEuropa (XIX-XX sec.) pela Università degli Studi della Tuscia (2015). Atualmente é Professor da Università degli Studi della Tuscia. (v.torreggiani@gmail.com)

Artigo recebido em 20 de janeiro de 2018 e aprovado para publicação em 22 de maio de 2018.
} 


\begin{abstract}
This article challenges a historiographical understanding of corporatism as an appendix of fascist ideology by examining the elaboration and diffusion of corporatist cultures in Britain during the first half of the $20^{\text {th }}$ century. The case study seeks, on the one hand, to highlight the changing nature of corporatism by showing the different forms - fascist and non-fascist - that it took in Britain in the given time period. On the other hand, the article connects British corporatism with the European corporatist movement, as well as with the British constitutional heritage, underlining the close entangling of national and transnational issues.
\end{abstract}

KEYWORDS: Corporatism; Great Britain; British constitutional history; Representation of organized interests.

\title{
RESUMO
}

0 artigo contesta um entendimento historiográfico do corporativismo como apêndice da ideologia fascista por meio da análise da elaboração e difusão de culturas corporativas na Grã-Bretanha na primeira metade do século 20. Este estudo propõe-se a destacar, de um lado, a natureza dinâmica do corporativismo, mostrando as diferentes formas - fascistas e não fascistas - que ele assume na cultura inglesa no referido período. De outro lado, o artigo estabelece as conexões com o movimento corporativo europeu e evidencia as particularidades do corporativismo inglês, associando-o com a herança constitucional britânica e, finalmente, mostrando a estreita interligação entre assuntos nacionais e transnacionais.

PALAVRAS-CHAVE: Corporativismo; Grã-Bretanha; História constitucional britânica; Representação dos interesses organizados.

\section{RESUMEN}

El artículo pretende rechazar la comprensión historiográfica del corporativismo como apéndice de la ideología fascista mediante un análisis de la elaboración y difusión de las culturas corporativas en Gran Bretaña durante la primera mitad del sigloXX. El estudio de caso tiene como finalidad afirmar, por un lado, la naturaleza dinámica del corporativismo, mostrando las diferentes formas - fascistas y no fascistas - que asume en la cultura inglesa de este periodo, así como las conexiones con el movimiento corporativo europeo. Por otro lado, el artículo pone en evidencia las particularidades del corporativismo inglés, relacionándolo con el legado constitucional británico por fin demostrando el estrecho vínculo entre asuntos nacionales e internacionales.

PALABRAS ClAVE: Corporativismo; Gran Bretaña; Historia constitucional británica; Representación de los intereses organizados. 
fter a quite obsessive academic attention received during the 1980 s, and an almost
silent disappearing from the scholarly radar occurred in the following decade, a recent revival of corporatist studies have led to a proliferation of researches, international conferences and volumes exploring the flourishing vitality of the corporatist body of thought in contemporary history (Costa Pinto, 2014, 2017; Pasetti, 2016). Certainly, as recalled by Molina and Rodhes, "the term Corporatism has been always characterised by ambiguity, imprecision, and a liberal, rather undisciplined usage" (Molina and Rodhes, 2002: 306). However, a renewed historical awareness has been revealing the nuances of a theory whose origins can be traced back to the $19^{\text {th }}$ century in different political and national cultures, well before the emergence of inter-war fascism.

Following this historiographical trend, this article deals with the diffusion of corporatist ideas in Britain in the first half of the $20^{\text {th }}$ Century. However, two elements must be recalled in order to present the particular case of study: first of all, the traditionally claimed endemic relationship between fascism and corporatism has to be rethought, particularly assessing the historical autonomy of the latter in respect to the former. Secondly, the transnational approach appears to be best suited so that one can deeply understand corporatism and its international diffusion, not for some alleged heuristic superiority of the transnational method, but simply because the very history of corporatist theories was itself transnational (Pasetti, 2016: 24). Surprisingly, among the several lists of corporatist authors and groups studied, there is still a certain lack of interest for the British case, which received just episodic and irregular attention (Shonfield, 1965; Beer, 1969; Carpenter, 1976; Ritschel, 1997; Stears, 2002). The country was often seen as somehow immune to fascism, and thus to a fascination for an institutional representation of economic interests. However, it is indeed in this perspective that assuming a rigid equivalence between corporatism and fascism fails to take account of several projects for the reorganization of society along corporatist lines promoted by non-fascist political subjects in largely non-fascist culture.

The article examines a series of British corporatist cultures developed in the first half of the $20^{\text {th }}$ century with a twofold objective: first of all, going beyond the linguistic issue, that is, proving their existence despite the names they adopt and understanding similarities, differences and connections between British and European corporatist intellectuals; secondly, investigating the relationship between the British corporatist ideas under examination and the legal tradition of the United Kingdom will allow us to deeply comprehend the interpenetration between national and trans-national issues in the developing of corporatist projects. Eventually, the thesis that will be tested is that in Britain corporatism was intended as a form of 
developing a new modern version of the medieval principle of the Government by Agreement in order to overcome the juridical-political crisis of the Liberal State.

\section{A RETROGRESSIVE PROGRESS: THE BRITISH CONSTITUTIONAL HERITAGE}

T he British Constitution is like an old man who still wears clothes in the fashion of his youth: what you see of him is the same; what you do not see is wholly altered" (Bagehot, 1867: 68). It is hard to find a more accurate and synthetic description of the British constitutional heritage than these words, written by Walter Bagehot in 1867.

A constitution is a set of fundamental laws on how a country is governed. Setting out the structure of the State, as well as the principle governing the relationship between the individual citizen and the State, and between the different parts of the State, constitutions organize, regulate and distribute powers. Although history has seen constitutions being codified in many different ways, in contemporary era the most common resultant of a constitutional process is a single legal document setting out, in one place, all the fundamental laws and principles on how the State works. However, Britain had been following a very different path, basing its State functioning on a multiplicity of legal documents, statuses, conventions, treaties and juridical decisions produced along a broad period of time, collectively forming the British Constitution.

Paraphrasing Jeffrey Goldsworthy's words, this progressively incremental constitutional process unfolds the inner un-revolutionary character of English-speaking people -perhaps it could be more accurate referring to the English élites - who appear to be permanently oriented towards a sort of legally conservative approach to socio-economic, political and technological changings (Goldsworthy, 2010: 2). In fact, even during explicitly revolutionary moments - such as, for instance, the civil war of 1640s, the Glorious Revolution of 1688 or the American Revolution of 1776 - the opposing parties strenuously claimed to defend the original and properly understood Constitution. Nevertheless, these conflicts indeed provided important mutations and advancements to the British constitutional corpus. In this sense, as recalled by A.V. Dicey in 1885, "the idea of retrogressive progress is merely one form of the appeal to precedent' (Dicey, 1885: 18), pointing out that in British legal history the "attempts at innovation have always assumed the form of an appeal to preexisting rights" (Dicey, 1885: 19). Therefore, it appears that the seamlessly British legal evolution shaped a constitution clothed with a pragmatic political attitude moulded in a slow and quiet adaptation to historical changes through a continuous interaction between tradition and innovation (Rebuffa, 1995: 30). 
From our point of view, it is important to highlight the consequences of a constitution relying on practices and conventions, especially in relation to the Industrial Revolution, the development of the bourgeois hegemony, and the emergence of a mass society. What stands out for its importance is that in Britain the modern bourgeois' citizen founds the very origins of their civil rights and liberties, not in a detailed written official document precisely accounting their rights and duties, but in a long evolution in full continuity with the medieval past and the modern era.

In this lapse of time, in fact, rather between the Magna Charta of 1215 and the Bill of Rights of 1689, we find the establishment and enforcement of the two juridical-political realities that eventually characterised the entire British constitutional path: the idea of the Rule of Law and the concept of Government by Agreement. If the former bore with itself the legal guarantees Habeas Corpus and the Trial by Jury - essential for the development of a modern capitalist economy -, it is the latter that seems to be a key element for our historiographical discourse. In fact, as stated in the Magna Charta, the idea of Government by Agreement refers to the definition of a formal normative agreement on how the country was to be ruled: an agreement signed by all the forces existing within the nation, political as well as economic; a contract enabling the different, opposing and potentially conflicting centres of power to formally establish their zones of action, rather than their rights and duties to jointly govern the public sphere. More than four centuries later, with the Bill of Rights of 1689, this medieval agreement officially evolved in one of the bedrock of the British public law, that is, the notion of the King in Parliament. After the Glorious Revolution, in fact, the concept of the King in Parliament re-expressed the vital necessity of a permanent agreement between the parts of the British nation, a nation threatened by internal fights, namely between landowner aristocracy and market/productive oriented bourgeois. The political and economic interests of the emerging capitalist modernity of the financial and commercial revolution were symbolically re-united by the famous triad of King, Lords and Commons. Since then, in order to enact a specific legislation, all the identified parts of the nation had to come to an agreement, within what became the privileged juridical locus of the decision-making process: the Parliament.

Thus, the British Constitution evolved through time always finding its benchmarks after eras of profound transformations and conflicts, such as the early medieval period and the $17^{\text {th }}$ century Glorious Revolution, eventually reinforcing at all steps a harmonious conception of legal and political order based on the idea of Government by Agreement. Basically, the political and juridical milieu constantly reacts to a crisis by advancing without destroying - innovations without revolutions - displaying a quiet and efficient adaptation of the rule-of-law to the 
changing socio-economic environment. As we will see shortly, the late $19^{\text {th }}$ century, the Industrial Revolution, with its major technological, socio-economic and political transformations, dangerously threatened to jeopardize (once again) the ancient order, putting the very survival of the bourgeois Liberal State at stake. In the transformation, a bunch of British intellectuals tried to find a remedy for the crisis of the Liberal State by re-enforcing the old principle of the Government by Agreement with corporatist elements, retrogressively finding the necessary constitutional advancement in the medieval past.

\section{ORDER, DISORDER AND REORDER}

Imost a decade ago, the British historian Richard Overy significantly titled his cultural and
intellectual history of inter-war Britain The Morbid Age, writing on the perceived crisis of civilisation (Overy, 2009). Interestingly, what emerges from Overy's description is a pervasive collective anxiety, not confined to a particular political space, regarding the decline of the Liberal political and legal tradition that Britain had done a good deal to build up in the first place.

Significantly, although explicitly prevalent in the inter-war years, the origins of this crisis can be traced back to the period between the end of the $19^{\text {th }}$ century and the beginning of the $20^{\text {th }}$, when the socio-economic and political consequences of the Industrial Revolution began to erode the actual functioning and the ideal essence of the Liberal State. In this sense, this is not an insular history: in fact, on the wave of the outburst of the social conflict and the emergence of the associations of organized interests, the $20^{\text {th }}$ century started in the whole Europe with a rediscovery of the socio-economic and juridical collective dimension that legal Liberal modernity had compressed. In the following decades, after the profound trauma of the Great War and later of the Great Depression, an intense distrust for old-political discourses, as well as for the traditional remedies for the economic problems, started to rise, becoming more and more common and encompassing different political cultures, movements and parties.

The shock of 1914 was particularly severe, mainly as a consequence of the juxtaposition of a pre-war illusion of indefinite progress with war and post-war socio-economic, political and humanitarian disaster. The rupture with the past was evident, especially for what has been self-called "the war generation" - among others, Oswald Mosley was a great supporter of this literary and political trope -, leading to rethink the very meaning of freedom and civil rights indeed. As R.H. Tawney cleverly summarized, the central disagreement of the age was exactly what freedom means and how it was to be reconciled with the desire of social unity (Stears, 2002: 24). 
Thus, alongside psychological and socio-economic fears brought to light by the Great War, what was in crisis was the image of Liberal bourgeois society, rather than a society relying on two mutually exclusive and opposed spheres of sovereignty: the individual, in the field of the dominium, rather than the domain of property and economic action; and the State, in the field of the imperium, the domain of command and community. Whether the Liberal culture recognized nothing in between of these two legal dimensions, at the turn of the centuries, modern industrial societies were experiencing an increasingly crowded middle-zone, composed by new political and economic organizations - such as parties, trade unions, agricultural and commercial leagues, industrial associations - that basically lied outside the rigid public-private Liberal dichotomy (Costa, 2001).

Well before World War I, and with an obvious hastening after it, a common sense of impending and unavoidable transformation reached many areas of the public discourse, shaping a series of concepts and metaphors concerning the idea of a Liberal State in crisis. The widespread perception was indeed one of decline and fall: the deterioration of a model of civil, political, juridical and economic cohabitation grounded on the $18^{\text {th }}$ and $19^{\text {th }}$ centuries' principles of individual freedom and rights. In this sense, the rising collective dimension not only started to demolish the authority of the old Liberal State, but also triggered a theoretical reaction within the political, juridical and economic arenas aimed at challenging the traditional understanding of social relationships. Therefore, between the midst of the $19^{\text {th }}$ century and the first half of the $20^{\text {th }}$, a series of authors started condemning liberalism as the main cause for turning society into a mass of atomistic self-seeking individuals after the rupture of the pre-modern social bonds. In the whole Europe the medieval corporatist society began to establish itself as an alternative model of organic organization for a harmonious and ordered community, opposed to the chaotic and conflicting capitalist society as well as to the rising socialist alternative (Black, 1984; Ornaghi, 1984).

In contemporary history, the corporatist model may be present in a variety of forms, countries and culture areas. Nevertheless, all of the corporatist proposals recommend, quoting Philippe Schmitter's frequently cited words, "a system of interest representation in which the constituent units are organized into a limited number of singular, compulsory, noncompetitive, hierarchically ordered and functionally differentiated categories" (Schmitter, 1974: 93). The final purpose of all the corporatist writers, although their proposals had different backgrounds, tools and objectives, was to institutionally recover a series of public areas of society detached from the power dimension of the State, eventually replacing the liberal individualistic socio-economic order with a collectivist, status-based and hierarchical one, where individuals' rights and duties reflect their status or function within the society. 
As put again by Philippe Schmitter, a corporatist theoretical tendency can be defined as a form of enacting an "institutional relationship between the system of authoritative decision-making and interest representation" (Schmitter, 1974: 87); or, as recalled more recently by Sabino Cassese, as "a way in which political power can reframe in a society invaded by social organizations which threat to jeopardize the traditional closed structure of the State" (Cassese, 2012: 96); or again, as underlined by Irene Stolzi, as "an opportunity, not only to reflect on trade unions and productive relations, but also, in more general terms, to provide an account of relations between the individual, State and social organizations" (Stolzi, 2014: 151). Put in these terms, the well-known fascist-authoritarian inter-war corporatist experiment appears to be just one of the several political discourses focusing on the representation of the economic interests as a medium to build a new institutional architecture fitted to govern the industrial society.

Focusing on the British reality, three political moments of corporatist elaboration were identified. The first one is a multifaceted and manifold intellectual network - the so-called New Age Circle - built up in 1907, where intellectuals and politicians coming from various political cultures gathered together around the figure of Alfred R. Orage, director of "The New Age". The second one is represented by a minority group within the Conservative Party led by Harold Macmillan who, after several initiatives - e.g. the Political and Economic Planning group (PEP), the Industrial Reorganisation League (IRL) - eventually drafted a legislative proposal in October 1934, titled The Industrial Reorganisation Bill. The third group is British Fascism, whose leader was Oswald Molsey, who established the British Union of Fascists (BUF) in October 1932 in order to adapt the Italian corporatist model in the United Kingdom.

\section{DIVERGENT AFFINITIES: A CORPORATIST LABORATORY}

I n 1907, Alfred R. Orage became the editor of the weekly review "The New Age". Through a tolerant and open-minded method of editorship, he soon established an informal network of contributors - the New Age Circle -, formed by intellectuals coming from the whole political spectrum, such as Arthur J. Penty, architect and social thinker; G.D.H. Cole and Samuel G. Hobson, two of the leading authors of Guild Socialism; G.K. Chesteron, Hilaire Belloc and Maurice Reckitt, Catholic thinkers profoundly influenced by the Rerum Novarum of Pope Leo XIII; and finally, Thomas E. Hulme, philosopher, scholar and translator of Nietzsche, Bergson and Sorel, and Ramiro De Maeztu, an Anglo-Spanish intellectual later advocate of Primo de Rivera and Francisco Franco. Since the informal nature of the network, it is impossible to iden- 
tify one single monolithic and coherent body of thought; rather, the circle symbolized a sort of a junction-point where different philosophies were knitting together in debates, discussions and disputes. However, although different, all of them appeared deeply involved in proposing corporatist solutions for a representation of institutional interests. Generally, four key political concepts seem to be working within the circle: ideas for a juridical personality of the socio-economic groups, spread by F.W. Maitland and J.N. Figgis; the social medievalist ideas of A.R. Orage and A.J. Penty; Social Catholicism, defended by G.K. Chesterton and H. Belloc; and finally, Guild Socialism, developed by G.D.H. Cole and S. G. Hobson.

Chronologically speaking, the first cultural experience that pre-dates some of the corporatist notions of the New Age Circle can be found in a different interpretation of the concept of juridical personality. Originally formed within the German Romantic Movement, the idea finds its way in Britain through the work of the historian and jurist Frederic W. Maitland and his disciple, the catholic thinker John N. Figgis. Both of them found a major source of inspiration in the ideas of the German thinker Otto Von Gierke and his most important work, the titanic Das Deutsche Genossenschaftsrecht, published in four volumes between 1868 and 1913. Undoubtedly, Maitland represents the key figure. He was one of the most important historians of English and European comparative jurisprudence, who in 1900 translated the third part of Von Gierke's work with the title of The Political Theories of the Middle Age.

Generally, Maitland and then Figgis' criticisms can be ascribed to the aforementioned theoretical juridical tension researching a new equilibrium between individuals, State and society in the light of the technological and sociological development triggered by the expansion of Capitalism. Both of them challenged the notion of isolated individual as the juridical basis of the society, arguing that the only real juridical person upon the national community that was built up was the group, socially and economically determined. According to Figgis, for instance, as he put in 1913, "the notion of isolated individuality is the shadow of a dream [...] in the real world, the isolated individual does not exist [...] and his personality can develop only in society" (Figgis, 1913: 88). Similarly, ten years before, Maitland stated that corporations are "a real thoroughly person with a real will" (Maitland, 1900: 15), specifying that a socio-economic group naturally possesses, per se, rights and duties with no need of other form of legal justifications from above. Affirming that "the corporation is [...] a right-and-duty-bearing unit" (Maitland, 1900: 15), Maitland was reshaping the first source of national sovereignty, which has to be found neither in the individual nor in the State, but in the socio-economic group: a fellowship of men united by a common interest or goal.

Almost in the same period, Arthur Penty and Alfred Orage were likewise developing a new interpretation of socialism, inspired by the ideas of Nietzsche and Bergson, as well as 
by the thinking of William Morris and John Ruskin, two important British intellectuals of the $19^{\text {th }}$ century. Six years after Maitland's translation of Von Gierke, Penty published one of the most important books for the corporatist thinking in Britain, titled The Restoration of the Gild System. Partially resolving the semantic rebus, Penty described his proposals as grounded on the concept of guild, using the medieval economic model as a solution to the industrial society's problems. Penty attacked socialist Collectivism in order to propose a different method to achieve socialist objectives. In his opinion, the fundamental flaw of Marxist socialism was to identify the main cause of the impoverishment of the working class in the capitalist economic competition. A private ownership of the means of production and wage labor system, according to Penty, was not bad in itself, but only in the socially disintegrating version of liberalism. Instead, a properly regulated economic market, such as the medieval one, could rather be a positive instrument of socio-economic, cultural and spiritual growth (Penty, 1906: 2-3).

The institution best suited to produce the required global changing in policy-making were indeed the guilds that, in Penty's words, "being social, religious, and political as well as industrial institutions, [...] postulated in their organization the essential unity of life" (Penty, 1906: 64). That perspective - clearly based on the class of producers, i.e. all the individuals in any form involved in the production process, rather than the working class - found its way within the New Age Circle and in Orage's ideas. In Orage's political perspective, the concept of socialism was experiencing a theoretical twisting, drifting away from its positivist roots and falling into an ambiguous cultural dimension. As shown by the British historian Tom Villis, Orage's socialist tendency was part of a common European attempt to dissociate socialism from its democratic and parliamentary overtones, freeing it from materialist and collectivist bias (Villis, 2006). In that respect, focusing principally on the moral question, Orage started soon to move away from a Marxist analysis of the capitalist society, i.e. an analysis based on class relations and social conflict, in order to embrace a strong nationalist agenda. During fifteen years - he resigned as editor of "The New Age" in 1921 -, he wrote extensively on these issues, forging a connection between a new notion of socialism and the idea of national welfare, with the final aim to propose an institutional system where the government was not monopolized by a single class, but rather shared among all parts of the nation.

Similarly and somehow consequentially, the New Age Circle resulted to be the hotbed of a number of unorthodox thinking claiming for a corporatist reorganization of the society, opposing what was perceived as crippling orthodoxies, both socialist and liberal. A prominent position is certainly occupied by Guild Socialism, whose theoretical foundations were poured in 1912-1914 on the pages of Orage's review by S.G. Hobson and G.D.H. Cole, who sooner 
became the most important intellectual of the movement. Proposing a sort of pluralist, left wing, anti-parliamentary but democratic corporatism, Cole presented his Guild Socialism as a plea for functional representation and functional democracy as against so-called purely political democracy, challenging the idea of traditional representative government and democracy.

Recalling Penty's notion of industrial guild, in Cole's hands (Guild) Socialism basically became a way to order and balance; to force the several socio-economic groups existing within the national community to cooperate: "true representation [...] is always specific and functional [...]. What is represented is never a man, the individual, but always certain purposes common to group of individuals" (Cole, 1919: 106). While remaining attached to a certain kind of democratic idea, the social engineering proposed by Guild Socialism aimed at provoking a revolution in the interpretation of the concept of democracy and sovereignty: the latter had to rest not in an abstract geographically elected Parliament, rather within the guilds, i.e. in the natural forces true expression of the modern industrial society (Cole, 1917, 1920). Thus, Cole's aspiration was to produce a new more reliable institutional architecture, decentralizing legislative powers into several specific, functional, industrial organisms and transforming the decision-making process in what Figgis defined "a society of societies" (Figgis, 1913: 49) in 1913.

Also late $19^{\text {th }}$ century social catholicism advocated similar notions. Intellectuals such as Giuseppe Toniolo, Emmanuel Von Ketteler, René de la Tour du Pin, and Pope Leo XIII were tackling an ineffectual liberal system by proposing the resurgence of a Christian medieval-type corporatist organization. Although supported by a minority, social catholicism had campaigners also in Britain. Among them, one of the key figures was Henry E. Manning, Archbishop of Westminster since 1865. At the turn of the centuries, Manning fulfilled a pivotal role within the British Catholic world, spreading the continental European ideas of Social Catholicism elaborated by the aforementioned intellectuals, with whom he carried a regular correspondence.

In 1906, Manning founded in London the Christian Socialist League in order to develop a political synthesis between catholic and socialist values and goals. Interestingly, among the members of Manning's League there were J.N. Figgis, Gilbert K. and Cecil Chesterton, and Hilaire Belloc, all interested in a corporatist reorganization of the institutional system and later contributors of "The New Age". Furthermore, besides writing for "The New Age", the Chesterton's brothers and Belloc also started their own reviews, namely "The Eye Witness" and "The New Witness" - transformed in 1925 in "The G.K.'s Weekly" - where they initiated to formulate a more recognizable version of British Social Catholicism, later labeled as Distributism. In 1926, a Distributist League was indeed established in London, advocating a widespread diffusion of small proprietors politically organized in economic guilds, where the general economic 
order had to be guaranteed by the institutional interaction between organized industrial and agricultural sectors.

Finally, concerning the New Age Circle, it has to be stated that it is almost impossible to provide a single satisfying definition for the cultural and political space produced by the intellectuals studied. The least that can be said is that the New Age Circle's writers produced ideas and theories that contained several themes, which have been seen as the distinctive characteristics of the pan-European revolt against positivism, parliamentary democracy and liberalism: a profound sense of cultural dislocation; a revolt against materialism and rationalism; a call for a new elite and for a moral renewal of the society; a strong anti-parliamentary, anti-liberal and anti-individualist feeling; and finally, the elaboration of proposals for a re-organization of the society, deeply permeated by a corporatist atmosphere.

\section{STATE AND INDUSTRY: CONSERVATIVE VARIATIONS ON THE CORPORATIST THEME}

fter the First World War, a minority group within the Conservative Party started to de-
velop a corporatist legislative proposal. Although several authors and politicians contributed to this political effort, a preponderant political figure led the entire process with his ideas and charisma, i.e. the post-war Prime Minister Harold Macmillan. After fighting in the war, Macmillan entered the House of Commons in 1924 and soon started to condemn the betrayal perpetuated, in his opinion, by the entire British political élite in respect to the sense of inter-class harmonic co-operation arose during the conflict. Macmillan's analysis was then strengthened by the several crisis punctuating the 1920s - such as the general strike of May 1926 and the economic world slump of 1929 -, which clearly demonstrated the flaws of a declining liberal and capitalist order. Although always remaining strongly anti-socialist, Macmillan tried to find a cure for the maladies of his time by building a third way political proposal, different from both liberalism and socialism, in order to regenerate a fragmented society by renewing the socio-economic and political mechanism.

The first step in this direction was the publication in 1927 of a volume entitled Industry and the State, co-authored with other young Conservative MPs, such as Robert Boothby and Oliver Stanley. The main goal of Macmillan's group was explicitly to elaborate an alternative between (and beyond) socialism and liberalism in order to correct the main flaws of both ideologies: as stated in the volume of 1927, "somewhere between the two extremes, between Marxian socialism and complete 'laissez-faire', must lie the land in which exploration is not 
only profitable but essential" (Boothby et al, 1927: 20). In this grey area, the young Tories hoped to find new theoretical justifications for the capitalistic society, correcting its manifest social flaws and eradicating class struggle.

On a legal perspective, a tertium collective dimension beyond private and public was identified as the institutional instrument to reconcile the (apparently) opposed needs of the individual and the society. While liberalism, by stressing the role of the individual, ignores the communal dimension of labour, socialism, by destroying private property, would eliminate the most important input of production and progress. Instead, in Macmillan's words, "the rights of the individual and of the community exist side by side" (Boothby et al, 1927: 138) and, far from being mutually exclusive, they represent two sides of the same coin. As it is distinctly expressed in the book, "individualism and collectivism are indeed but two ways of looking at the same thing - both necessary and each the complement of the other. [...] Their reconciliation is the need, which the theory of a social contract seems designed to meet" (Boothby et al, 1927: 138). In fact, while the individual deserved a reward for his own productive effort, society as a whole was entitled to receive all the benefits derived from the co-operative aspect of that effort.

The new political system envisaged by Macmillan and his group of young Tories had the goal to guarantee the expression of the needs and wishes of those directly engaged in the productive system. It was a sort of economic democracy, in which the industrial world was invested with the right to officially participate in the decision-making process concerning political economy through sectorial economic agencies: "the object of Conservative policy [...] - it is stated in this volume - should rather be to create a system under which industry should be as far as possible self-governing" (Boothby et al, 1927: 180).

Thereafter, in Macmillan's mind, the economic crisis of 1929 represented the final act in the failure of orthodox economic policies and in the decline of the capitalist system. After the Great Slump, Macmillan intensified his efforts to elaborate a plan for constructing a corporatist society. During these years, he worked hard to construct his peculiar third way, writing several essays - the most important ones were The State and Industry and The Next Step, both written in 1932 and unpublished, and Reconstruction, published in 1933 - and founding in 1933 with Henry Mond a pressure group called the Industrial Reorganisation League (IRL). Therefore, the reflection started in the second half of the 1920s was further enhanced during this period, always looking for a new kind of system. In that respect, Macmillan affirmed that he believed the proper substitute for the individual to be not the State, but functional economic groups, thus replacing individual initiative with a whole industry initiative (Macmillan, 1932). 
Henry Mond, like Macmillan, championed a corporatist reorganization of society, as clearly stated in his book Modern Money published in 1932. However, more than Macmillan, he was intensely fascinated and influenced by the Italian Corporatist State created in the same years, which he described as a new guild system. Explicitly referring to this system, in his volume, Mond proposed the establishment of a bicameral political scheme, in which an elected, traditional Parliament had to be matched by an industrial Parliament formed by representatives of the economic world with the power to debate and enact economic legislation (Mond, 1932: 213).

In the same period, another unorthodox conservative study group on similar issues - the Political and Economic Planning (PEP), established in 1931 - was emerging. Working in close relations, the IRL and the PEP eventually drafted two extremely similar legislative proposals, respectively called Industrial Reorganisation Bill and Self-Government for Industry Bill. Both the proposals were based on the idea of establishing a form of industrial self-government. According to the authors, each economic sector had to be reorganized in a single common agency in order to satisfy its needs in continuous talks with other economic agencies as well as with the Government. The entire economic policy of the country would be controlled by a National Industrial Council, composed by the representatives of the various economic agencies.

The Parliament did not disappear from the political machinery proposed. However, it was relegated to a minor role, namely to accept or refuse the economic legislation elaborated elsewhere, with no power to modify or improve it. Westminster, in fact, was seen as a functional agency itself, representative of the consumer category, the last piece of the legislative process in economic matters. The resulting polycentric architecture based on functional groups intended to shape a democratic system profoundly different from liberal democracy, mainly because it was founded not on individuals' political choices, but rather on the concept of function and productive unity. In fact, in this new kind of industrial democracy, individuals and their opinions were no longer central to the representative system: in their stead there were the ideas, needs, and necessities of the productive sectors and economic interests.

After being approved by the Conservative Party Conference, the Industrial Reorganisation League draft was debated in Parliament, firstly in the House of Lords during the sitting of the $31^{\text {st }}$ of October 1933, and then in the House of Commons, on the $3^{\text {rd }}$ of April 1934. Even though Macmillan formed a transversal front in supporting his bill, he was eventually sustained only by the minority of the Conservative Party and by few MPs of Macdonald's National Labour group. Severe criticisms came, as expected, especially from the Labour Party, but Macmillan's proposal was criticised also by the Federation of British Industries, reluctant 
to fulfil a public role; by the liberal press, such as The Times and The Economist; and, finally, by orthodox liberal academics, such as Friederich Hayek and Lionel Robbins. Moreover, the majority of the Conservative Party eventually came to refuse the legislative bill promoted by the Industrial Reorganisation League. A Conservative Party Committee set up in April 1934 in order to study Macmillan's proposal, chaired by Neville Chamberlain, drafted in April 1935 its final report, rejecting the very idea of planning. The Committee's report clearly distinguished between the concept of industrial control, which had to be firmly refused, and the idea of industrial assistance furnished by the Government in case of emergency, which was regarded as the only possible kind of State intervention in the economic field (Ritschel, 1997: 144-231). In the end, Macmillan's attempt to enact corporatist legislation in Britain failed. The general rejection of the bill put an end to the campaign for a corporatist-capitalist reorganization scheme. The IRL's bill was never published and the association was soon disbanded.

\section{IMPORTING A MODEL: BRITISH FASCISM AND ITALIAN CORPORATISM}

In

$\mathrm{n}$ the same period, another important figure of the British corporatist world was emerging:

Oswald Mosley. After resigning from Macdonald's Labour government of 1929, Mosley firstly launched the New Party at the beginning of 1931, pursuing a generational approach to the social and economic problems of his time (Worley, 2010). As pointed out in the first article written after his resignation, What Am I Fighting For, Mosley believed that the Great War was a decisive breaking point in world history and, therefore, both pre-war politicians and ideologies were absolutely incapable of dealing with the major issues of the post-war world. The electoral failure of the New Party at the elections of October 1931, and Mosley's growing fascination with a fascist-type ideology, led him into an intense transformation phase. After dismissing the New Party at the end of 1931, Mosley travelled through Italy. In the first months of 1932, he met Mussolini in person and, after his return to London, he founded the British Union of Fascists in October 1932 (Lunn and Thurlow, 1980; Linehan, 2000; Derril, 2006; Pugh, 2006; Howell, 2015).

Mosley spent the entire summer of 1932 writing the fundamental document of British fascism, The Greater Britain, which was coupled by other publications specifically concerning the Corporatist State, whose author was Alexander Raven Thomson, one of the most important corporatist intellectuals of Mosley's movement. The rationale behind the thinking of Mosley, Thomson and the entire British fascist élite was basically to reproduce the Italian model in 
the United Kingdom. The central problem of the malfunctioning of the Liberal democracy was, again, the lack of economic competences expressed by Westminster, defined as a "non-technical assembly in a vastly technical age" (Mosley, 1932: 29).

On the constructive side, in order to restore a well-functioning authority of the Government and Parliament, Mosely proposed that "fascism would replace the present House of Lords by a Second Chamber of specialists" (Mosley, 1932: 41). This Second Chamber had to be the apex of a new institutional system grounded on industrial corporations, each one responsible for a specific economic sector and formed by all the producers working in that sector. The corporatist mechanism had to function as a way to introduce all the socio-economic organizations, which were born outside the Liberal State, into a new Corporatist State through their transformation in State institutions. As put by Thomson in 1935, all the "existing organizations will be woven into the fabric of the Corporate State" (Thomson, 1935: 165).

The notion of the producer, as in the Italian fascism, symbolised the ideal reference image, exemplifying the desire of overcoming class war in order to build a new harmonic society. As put by Mosley "the producer, whether by hand or brain or capital, will be the basis of the nation" (Mosley, 1932: 35). If the productive moment represented the common interest to all the social classes, the Nation was regarded as a superior and metaphysical entity "with a purpose, a life, and means of action transcending those of the individuals of which it is composed" (Thomson, 1935: 165). After 1935-1936, Mosley's British Union of Fascists became progressively radical, starting to apply violent Nazi-style methods, as represented by the frequent clashes with the opponents, such as the Battle of Cable Street in London's East End in October 1936. In this period, Mosley's support started to further decline and in 1940 his party was disbanded following the Defence Regulation 18B enacted by the Parliament as World War Il broke out.

\section{CORPORATISM AND THE BRITISH CONSTITUTION: CONTINUITY AND CHANGE}

T he present article was designed to investigate the diffusion of corporatist ideas in the United Kingdom in the first half of the $20^{\text {th }}$ century. The research has shown through the entire period a surprisingly liveliness of ideas for established in Britain a corporatist interest representation system, although these proposals - with the exception of the fascist one - were rarely labelled as "corporatist". Assuming that the core of all the modern corporatist doctrines is the institutionalisation of a representation of economic interests - variously modulated 
and proposed - one of the most interesting findings of the research was indeed proving the existence of a multiple British political and economic debate that could be ascribed to the European and global season of corporatist fascination. In fact, although different, all of the theoretical experiences analysed shared a common interest in transforming producers' organizations from voluntary and private representative bodies in regulatory public agencies, participating and enforcing political decisions. Under corporatism, renewed socio-economic interests organizations became the juridical and political organisms to build up a new institutional architecture able to harmonise the different and conflicting interests existing within the Nation.

Certainly, British intellectuals formulated their corporatist proposals according to their long-term political and juridical tradition and costumes. However, as in other parts of the world, the cornerstone of the proposed industrial and institutional reorganization was classifying and systematizing mass society, including all the socio-economic organisations developed outside the boundaries of the old Liberal State in a new shaped decision-making process in order to valorise their technical competences, as well as to ensure the end of class struggle. Thus, in the first half of the $20^{\text {th }}$ century, British corporatism appears to be one of the many epicentres of the European and global corporatist theoretical space. In this sense, corporatism can be interpreted as a polycentric family of corporatist correspondences that have to be appreciated in their complex relationship of similarities and differences; in their different grades of institutional development and theoretical sophistication; in their forms of convergence, divergence and entanglement.

However, beyond the comparative perspective, another aspect deserves to be discussed. Escaping the spectre of a short-term history led to an attempt to link the corporatist proposals here presented with the peculiar British constitutional history. The result was surprisingly dense of consequences for the general interpretation of the case study. In fact, it is indeed in relation with the British unwritten constitution that the corporatist theories here analysed fully reveal their complex net of historical connections with a particular juridical-political past.

As already recalled, Britain constitutional functioning is based on a peculiar complex of laws, practices and conventions that have evolved through a long period of time. Paradoxically, the British constitutional development is as rich as lacking of authentic constituent moments: what stands out for its macroscopic importance, for instance, is the absence of a traumatic fracture, such as the French Revolution was for the rest of Europe in 1789. Therefore, its unwritten nature gave life to a historical constitutional profile that seems to rely on a fluid and flexible continuity between past and present (Bruschi, 2014: 19).

That model brings two relevant consequences on the theoretical side. The first one was the refusal of the French revolutionary concept pair of "constituent power-general will"; while 
the second was the absence of the very notion of Ancien Régime, seen as an entire system of practices, ideologies and conventions to eradicate (Fioravanti, 2016: 70). Thus, in Britain, the possibility for a sovereign power to decide about the whole political system was always regarded as artificial and potentially damaging the solidity of the society; therefore destabilising the social and political order. In this sense, the French revolutionary initiative to artificially create a complete new order through the Constituent Assembly provoked in Edmund Burke a sense of "disgust and horror" (Burke, 1790: 29) because the French Revolution indeed lacked of the British "entailed inheritance" (Burke, 1790: 30), i.e. of an inner adaptive capacity for historical development. In this sense, the British constitutional space was never at the mercy of any new powers, but was protected by its own long history in continuity with its medieval past, and not in contrast as in the rest of Europe.

Concluding, it is in the light of this strong medieval tradition that the corporatist British proposals show their second nature and reveal themselves as political itineraries of cultural continuities and discontinuities. In fact, if the British corporatist authors were - each one in their own way - remarkably opposed to a glorious tradition of political and economic individualism, claiming for a re-organization of the institutions along corporatist lines; they also showed a (non) surprisingly dose of continuity with the British constitutional culture of which they revealed to be, if carefully observed, truthful heirs. In fact, what they proposed was never a constituent act or assembly, but rather a renewal of the old Government by Agreement idea. In permanent dialogue with the past, they praised for the commitment (once again) of all the various political and economic powers of the industrial society to cooperate in order to permanently resolve the increasing tensions between the individual, the groups and the community. In their opinion, in the light of the industrial revolution, what was lacking was a satisfying identification of these powers. It is in this sense that, in their opinion, the industrial society demanded the introduction of a fourth element in the constitutional equation alongside King, Lords and Commons, in order to ensure a durable stabilization through a competent, balanced and stable government. That element was the Industry, i.e. the economic representation that had to join the traditional constitutional triad in order to establish a new Government by Agreement. 


\section{BIBLIOGRAPHY}

BAGEHOT, Walter. The English Constitution. London: Chapman \& Hall, 1867.

BEER, Samuel. Modern British Politics: Parties and Pressure Groups in the Collective Age. London: Faber, 1969. BLACK, Anthony. Guilds and Civil Society in European Political Thought from the Twelfth Century to the Present. London: Methuen, 1984.

BOOTHBY, Robert et al. Industry and the State: A Conservative View. London: Macmillan, 1927.

BRUSCHI, Ugo. Rivoluzioni silenziose: I'evoluzione costituzionale della Gran Bretagna tra la Glorious Revolution e il Great Reform Act. Santarcangelo di Romagna: Maggioli, 2014.

BURKE, Edmund. Reflections on the revolution in France. Dublin: W.Watson, 1790.

CASSESE, Sabino. Lo stato fascista. Bologna: II Mulino, 2010.

COLE G. D. H. Guild Socialism Re-Stated. London: Leonard Parsons, 1921. Self-government in industry. London: G. Bell, 1917. The Social Theory. London: Methuen \& Co., 1919.

CORRIN, Jay P. Catholic Intellectuals and the Challenge of Democracy. Notre Dame (IN): Notre Dame University Press, 2002.

COSTA, Pietro. Civitas: storia della cittadinanza in Europa IV. L'età dei totalitarismi e della democrazia. Roma-Bari: Laterza, 2001.

COSTA PINTO, António. Corporatism and Fascism: the corporatist wave in europe and Latin America. London: Routledge, 2017.

0 corporativismo nas ditaduras da época do Fascismo. Varia Historia, v. 30, n. 52, 2014.

DANGERFIELD, George. The Strange Death of Liberal England. New York: Capricorn Books, 1935.

DICEY, Albert Venn. An Introduction to the Study of the Law of the Constitution. London: Macmillan, 1885.

DORRIL, Stephen. Blackshirt: Sir Oswald Mosley and British fascism. London: Viking, 2006.

FERRAL, Charles (Ed.). Modernist Writers and Reactionary Politics. Cambridge: Cambridge University Press, 2001.

FIGGIS, John Neville. Churches in the modern State. London: Longman, 1913.

FIORAVANTI, Maurizio. La Magna Charta nella storia del costituzionalismo. Quaderni Fiornetini per la Storia de Pensiero Giuridico, v. 45, 2014.

GAGLIARDI, Alessio. I/ corporativismo fascista. Roma-Bari: Laterza, 2010.

GOLDSWORTHY, Jeffrey. Parliamentary Sovereignty: Contemporary Debates. Cambridge: Cambridge University Press, 2010.

HOWELL, David. Mosley and British politics 1918-32. Basingstoke: Palgrave Macmillan, 2015.

JACKSON, Paul. Great War Modernism and "The New Age" magazine. London: Bloomsbury, 2012. 
LINEHAN, Thomas. British Fascism 1918-1939: Parties, Ideologies, and Cultures. Manchester: Manchester University Press, 2000.

LUNN, Kenneth; THURLOW, Richard C. (Ed.). British fascism: essays on the radical rights in interwar Britain. London: Croom Helm, 1980.

MACMILLAN, Harold. Reconstruction: A Plea for a National Policy. London: MacMillan, 1933.

. The Next Step. 1932. Unpublished..

. The State and industry. 1932. Unpublished..

MATILAND, Frederic W.; H.A.L. Fisher (Ed.). The Collected Papers of Frederic William Maitland. Cambridge: Cambridge University Press, 1911.

MARTIN, Wallace. The New Age Under Orage: chapters in English Cultural History. Manchester: Manchester University Press, 1967.

MOLINA, Oscar; RODHES, Martin. Corporatism: The Past and Present of a Concept. Annual Review of Political Science, v. 5, 2002.

MOND, Henry. Modern Money: a Treatise on the Reform of the Theory and Practice of Political Economy. London: Martin Secker, 1932.

MOSLEY, Oswald. The Greater Britain. London: BUF, 1932.

NICHOLLS, David G. The pluralist State. London: Macmillan, 1975.

ORNAGHI, Lorenzo. Stato e corporazione: Storia di una dottrina nella crisi del sistema politico contemporaneo. Milano: Giuffrè, 1984.

OVERY, Richard. The morbid age: Britain and the Crisis of Civilization, 1919-39. London: Allen Lane, 2009.

PASETTI, Matteo. L'Europa corporativa: una storia transnazionale tra le due guerre mondiali. Bologna: Bononia University Press, 2016.

PENTY, Arthur J. The Restoration of the Gild System. London: Swan Sonneschein and Co., 1906.

PUGH, Martin. Hurrah for the Blackshirts: fascists and fascism in interwar Britain. London: Pimlico, 2006.

REBUFFA, Giorgio. Un'idea di costituzione - Walter Bagehot e la regina Vittoria. In: BAGEHOT, Walter. La Costituzione inglese. Bologna: II Mulino, 1995.

RITSCHEL, Daniel. The Politics of Planning: The Debate on Economic Planning in Britain in the 1930s. Oxford: Oxford University Press, 1997.

SCHMITTER, Philippe. Still the Century of Corporatism? The Review of Politics, v. 36, n. 1, 1974.

SHONFIELD, Andrew. Modern Capitalism: The Changing Balance of Public and Private Power. London: Oxford University Press, 1969.

STEARS, Marc. Progressives, Pluralists, and the Problems of the State. Oxford: Oxford University Press, 2002.

STOLZI, Irene. L'ordine corporativo: poteri organizzati e organizzazione del potere nella riflessione giuridica dell'Italia fascista. Milano: Giuffrè, 2007. 
Private, public and collective: the twentieth century in Italy from fascism to democracy. In: RASK, Mikael; THORNHILL, Chris (Ed.). Law and the formation of modern Europe: perspectives from the historical sociology of law. Cambridge: Cambridge University Press, 2014.

TAYLOR, Gary. Orage and the new age. Sheffield: Sheffield Hallam University, 2004.

THOMSON, Alexander R. The Coming Corporate State. London: Action Press, 1935.

The Economics of British Fascism. London: Bonner, 1933.

VILLIS, Tom. British Catholics and Fascism: Religious Identity and Political Extremism Between the Wars. London: Palgrave Macmillan, 2013.

Reaction and the Avant-Garde: the revolt against liberal democracy in the early twentieth-century Britain. London: Tauris, 2006.

VON GIERKE, Otto. Political Theories of the Middle Ages. Translated with an introduction by F.W. Maitland. Cambridge: Cambridge University Press, 1900.

WRIGHT, A.W. G.D.H. Cole and Socialist Democracy. Oxford: Clarendon Press, 1979. 
